\title{
Ellipsis
}

2015

\section{The Impulse Purchase}

\author{
Kia Groom
}

Follow this and additional works at: https://scholarworks.uno.edu/ellipsis

\section{Recommended Citation}

Groom, Kia (2015) "The Impulse Purchase," Ellipsis: Vol. 42 , Article 10.

DOI: https://doi.org/10.46428/ejail.42.10

Available at: https://scholarworks.uno.edu/ellipsis/vol42/iss1/10

This Poetry is brought to you for free and open access by the Department of English and Foreign Languages at ScholarWorks@UNO. It has been accepted for inclusion in Ellipsis by an authorized editor of ScholarWorks@UNO. For more information, please contact scholarworks@uno.edu. 


\title{
The Impulse Purchase
}

\author{
Kia Groom
}

Andrea Saunders Gereighty / Academy of American Poets Award Winner

I am G's sexy PEZ dispense-

her. Open wide, he says,

\& show me all

that sweet. My knees are weak.

My knees are knees repeating sing-

song jingle tones to floorboard cracks.

G holds my head. Sharp

fingers push, he says you all look the same

With your necks pushed back.

My jaw-spring creaks. I stare

plastic as $\mathrm{G}$ tells me all

the holes he bodies:

fox holes, wormholes, grave

holes, holes in pipes \&

in flesh-lights \& secret soft

wet holes in all our bodies.

$\mathrm{G}$ fills so many holes that he forgets

to fill himself. He thinks in hole \& not

hole. When my mouth is open I am not

hole. You want this, G reminds me,

slicking my cartoon lips,

you want to be collectible, 
cheap and precious. I count

the times I've swallowed:

six months learning dislocation, six

months apprenticing to death, \& six

white pills that rattle in my skull

to keep me useful. My gullet

is a two-way street. I pump

up candy. G says open

wide he says snap back the hole

in your neck he says

I have something you can do with that two-dollar wince. 